\title{
New Media, Old Journalistic Work Routines
}

\section{Carles Pont-Sorribes* and Sergi Cortiñas-Rovira}

Department of Communication, University Pompeu Fabra Barcelona, Spain

The new information technology has changed the journalism. Web 2.0 [1] has broken the exclusivity of traditional media as transmitters of information. The advent of technological advances leads, as Castells [2] says, to the creation of a network of networks, the so-called networksociety. In this society there is a new user model: "prosumers". They are proactive consumers of information, as many scholars reveal. This change is the big Achilles heel of journalism and traditional media.

The authors of this article have observed the change in the journalism profession especially in the research project [3] about science journalism in Spain. In this research we have studied how new technologies affect traditional media. These changes have positives and negatives aspects for the journalism as a profession. Some conclusions of our research reveal that blogging, like a Twitter and Facebook platforms, have changed the production of information in the newsrooms. Specifically, new technologies have become a new source of information for journalists, have accelerated the process of information production and have carried changes in work routines.

Web 2.0 is an important new source for science journalists. Most journalists say they don't' have to look for the news "under the street", because new technologies have become a tool for information search. Speed is one other change. The $88 \%$ of Spanish Science Journalists believe that speed allows more relationship between the scientific communities, but they also think that is not good for journalism profession. Speed is very bad because doesn't permit a good check of sources and cause a lot of mistakes.

A positive aspect of the new technologies is that science journalists believe there is a great improvement with their audience interaction. $80 \%$ of journalists surveyed in the investigation say that social web has allowed them to have a more fluid dialogue with their audiences and this has enabled them to have more feedback from the news they publish.

One of the major problems pointed out in our research is the alarming proliferation of pseudosciences, defined as false knowledge (or false science), in Spanish media. With new technologies, the set of pseudoscientific practices found new channels to express and to reproduce its discourses. Scientific knowledge is a substantial part of "high culture" and should be preserved. It is not admissible that the media relax its controls against the flood of pseudoscientific content which is trying to penetrate in agenda every day.

This research has shown that these controls have too often been defective in Spain. Another reason for this proliferation of pseudoscience has been, according to interviewed science journalists, the lack of trained staff in science subjects among high responsible staff, i.e between those who take the key decisions.

Our work also identifies a growing phenomenon in the field of science journalism, but it probably happens in a similar measure in other areas such as politics, economics and sports. In a moment of structural weakness for media, particularly because of the economic crisis, which has been especially bloody in southern Europe, there is evidence of a slow but steady process of "colonization" of the journalist profession by the public relation staff of companies and institutions.
The best science journalists are hired by top pharmaceutical, medical, chemical or oil companies to work in its press office department. This is a serious loss for the free flow of independent information, since the best journalists -often the most critical ones- disappear. And what is worse, they are often replaced by other ones, younger and cheaper, with a little preparation and almost no critical capacity or expertise to exercise a critical work as their ancestors had developed.

This situation leads to a delicate scenario: with increasing strong companies communicatively, with extremely powerful media departments, and with increasing weak Media, with a lot of economic problems, which are devoid of his most remarkable talent. And everybody knows this lesson: without critical journalists, without free press, democracy tends to evaporate.

There are evident changes in the professional routines of journalism world, but certainly we are not in the death of the profession. Journalism needs to adapt to the new media without forgetting the old recipes of the production of the piece of news: search of information, check it and spread the news. The ones that will best adapt to the needs of change will have life for many years.

\section{References}

1. The term was coined in 1999 by Darcy DiNucci and was popularized by Tim O'Reilly in 2004.

2. Castells, Manuel (1996) The Rise of the Network Society, The Information Age Economy, Society and Culture. Oxford: Blackwell 1, USA.

3. This research was supported by the Spanish Ministry of Economy and Competitiveness through the $\mathrm{R}+\mathrm{D}+\mathrm{l}$ project, led by Sergi Cortiñas as principal investigator and titled 'Science journalism in Spain and the new information technologies: situational snapshot and proposals for action to improve communication processes' (CSO2011-25969, 2012-2014).

*Corresponding author: Carles Pont-Sorribes, Department of Communication niversity Pompeu FabraBarcelona, Spain, Tel: 93-542-22-86; E-mail: carles.pont@upf.edu

Received September 10, 2013; Accepted September 11, 2013; Published September 12, 2013

Citation: Pont-Sorribes C, Cortiñas-Rovira S (2013) New Media, Old Journalistic Work Routines. J Mass Communicat Journalism 3: e142. doi:10.4172/2165$7912.1000 \mathrm{e} 142$

Copyright: (c) 2013 Pont-Sorribes C, et al. This is an open-access article distributed under the terms of the Creative Commons Attribution License, which permits unrestricted use, distribution, and reproduction in any medium, provided the original author and source are credited. 